\title{
ASSESSMENT OF THE LOGISTIC SYSTEM OF FUEL LIFE CYCLE USING THE LCA METHOD
}

\author{
Aleksander Marek ${ }^{\mathrm{a}}$, Piotr Kardasz ${ }^{\mathrm{b}}$, Mikolaj Karpinski ${ }^{\mathrm{a}}$, Volodymyr Pohrebennyk ${ }^{* \mathrm{a}, \mathrm{c}}$ \\ ${ }^{a}$ Institute of Technology, The State Higher Vocational School in Nowy Sacz \\ ${ }^{\mathrm{b}}$ Faculty of Automatic and Robotics, Wroclaw University of Applied Informatics \\ c Vyacheslav Chornovil Institute of Ecology, Nature Protection and Tourism, Lviv Polytechnic \\ National University, Lviv, Ukraine \\ *Corresponding author: e-mail: vpohreb@gmail.com
}

\begin{tabular}{|c|c|}
\hline ARTICLE INFO & ABSTRACT \\
\hline $\begin{array}{l}\text { Article history: } \\
\text { Received: September } 2015 \\
\text { Received in the revised form: } \\
\text { December } 2015 \\
\text { Accepted: May } 2016 \\
\end{array}$ & $\begin{array}{l}\text { This paper presents the logistic system of fuel life cycle, covering } \\
\text { diesel oil and the mixture of rapeseed oil and butanol ( } 2: 3 \text { ratio), using } \\
\text { the Life-Cycle Assessment (LCA) method. This method is a technique } \\
\text { in the field of management processes with a view to assessing the } \\
\text { potential environmental hazards. Our intention was to compare the }\end{array}$ \\
\hline $\begin{array}{l}\text { Key words: } \\
\text { life cycle, } \\
\text { logistic system, } \\
\text { LCA method, } \\
\text { environmental hazards }\end{array}$ & 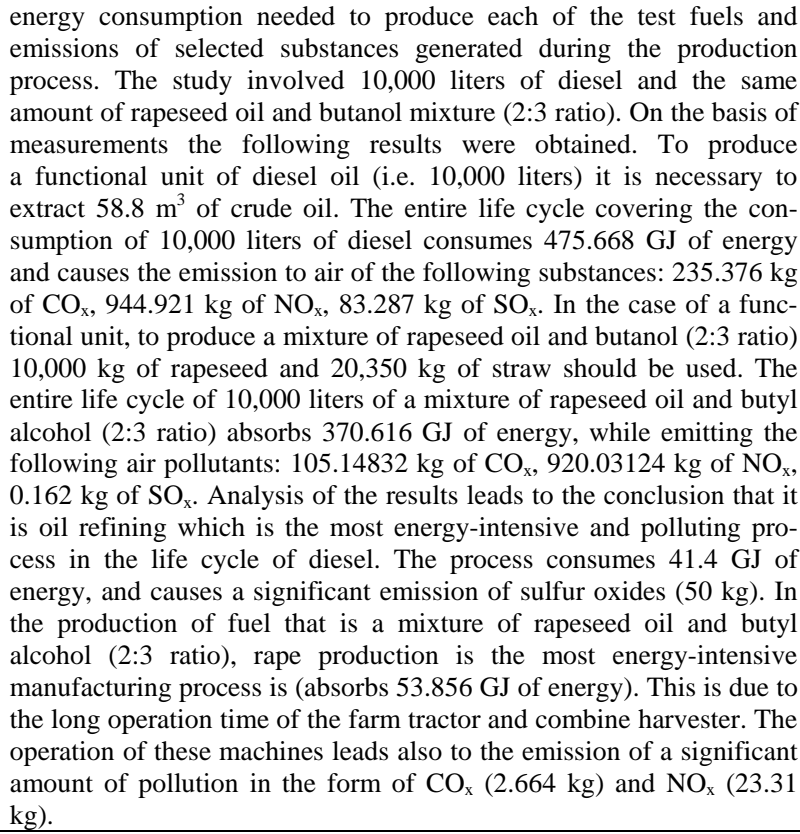 \\
\hline
\end{tabular}




\section{Introduction}

Life Cycle Assessment (LCA) is a technique in the field of management processes with a view to assessing the potential environmental hazards (Gilecki, 2003; Gutkowski, 2002; Góralczyk i Kulczycka, 2001). The essence of this method is evaluation of not only the final result of the process but also evaluation and assessment of the impact of the whole process on the environment. The assessment relates to the entire cycle of product life or activities covering mining and processing of mineral raw materials, the manufacturing process of the product, distribution, use, reuse, maintenance, recycling, final land use and transportation. LCA covers the environmental impact study system of product in the area of the ecosystem, human health and waste of resources (Kulczycka et al. 2001; Lagerstedt et al. 2003).

The life cycle refers to the view that a fair, holistic assessment requires the assessment of raw material production, manufacture, distribution, use and disposal, including all past stages of transportation necessary for the product to exist. Thus, LCA is a process of evaluation of the effects which products exert on the environment throughout their lives, through an increase in the effective use of resources and reduction of environmental burdens (fig.1). LCA is used to determine the environmental impact on the decision or proposed changes, usually oriented towards the future. This means that the whole market and the economic consequences of a decision may be taken into account. Procedures for Life Cycle Assessment are part of the ISO 14001 environmental management standard, ISO 14040:2006 and 14044:2009. (ISO 14044:2009 replaces the earlier versions of ISO 14041 and ISO 14043). (ISO 14040, ISO 14041, ISO 14042, ISO 14044).

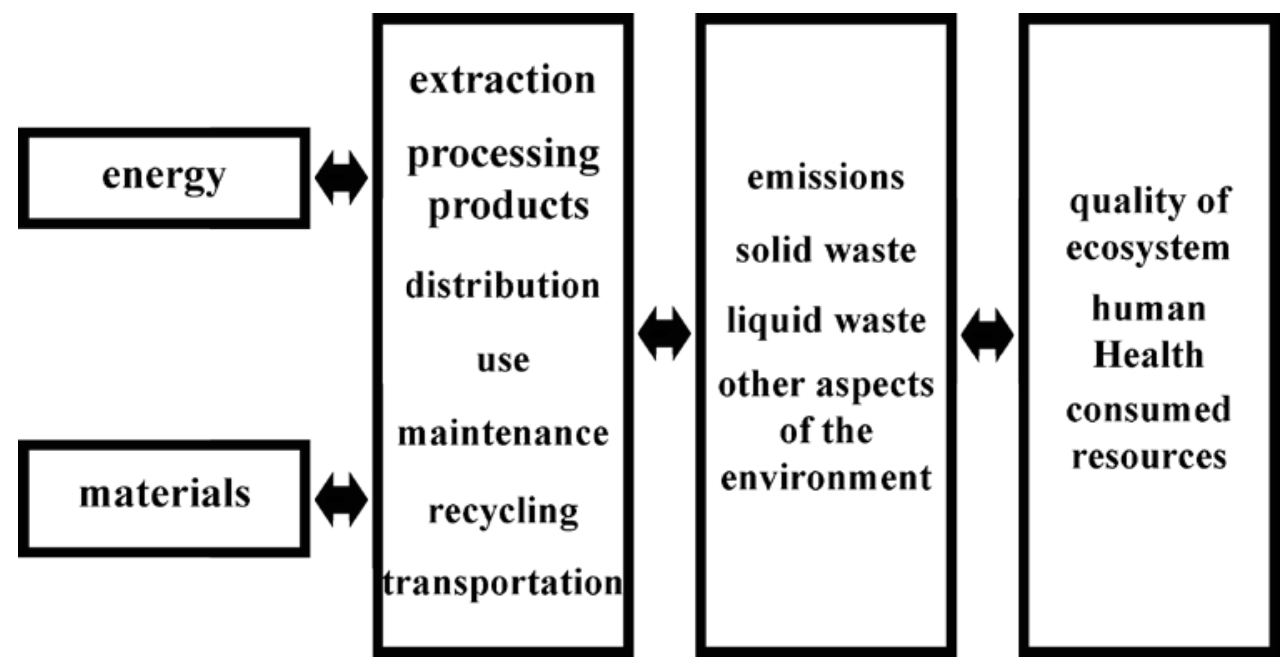

Figure 1. Environmental life cycle assessment (Kulczycka, 2001) 
A definition of the environmental life cycle assessment takes into account the following four stages of work:

- determination of the purpose and scope of research;

- creation of a set of inputs and outputs;

- assessment of the impact on the environment;

- interpretation of the life cycle.

The first step in determination of the scope of LCA will describe the system and its boundaries. This will allow for the analysis of the phases of the production process and allow determination of the required energy consumption in the process (fig.2).

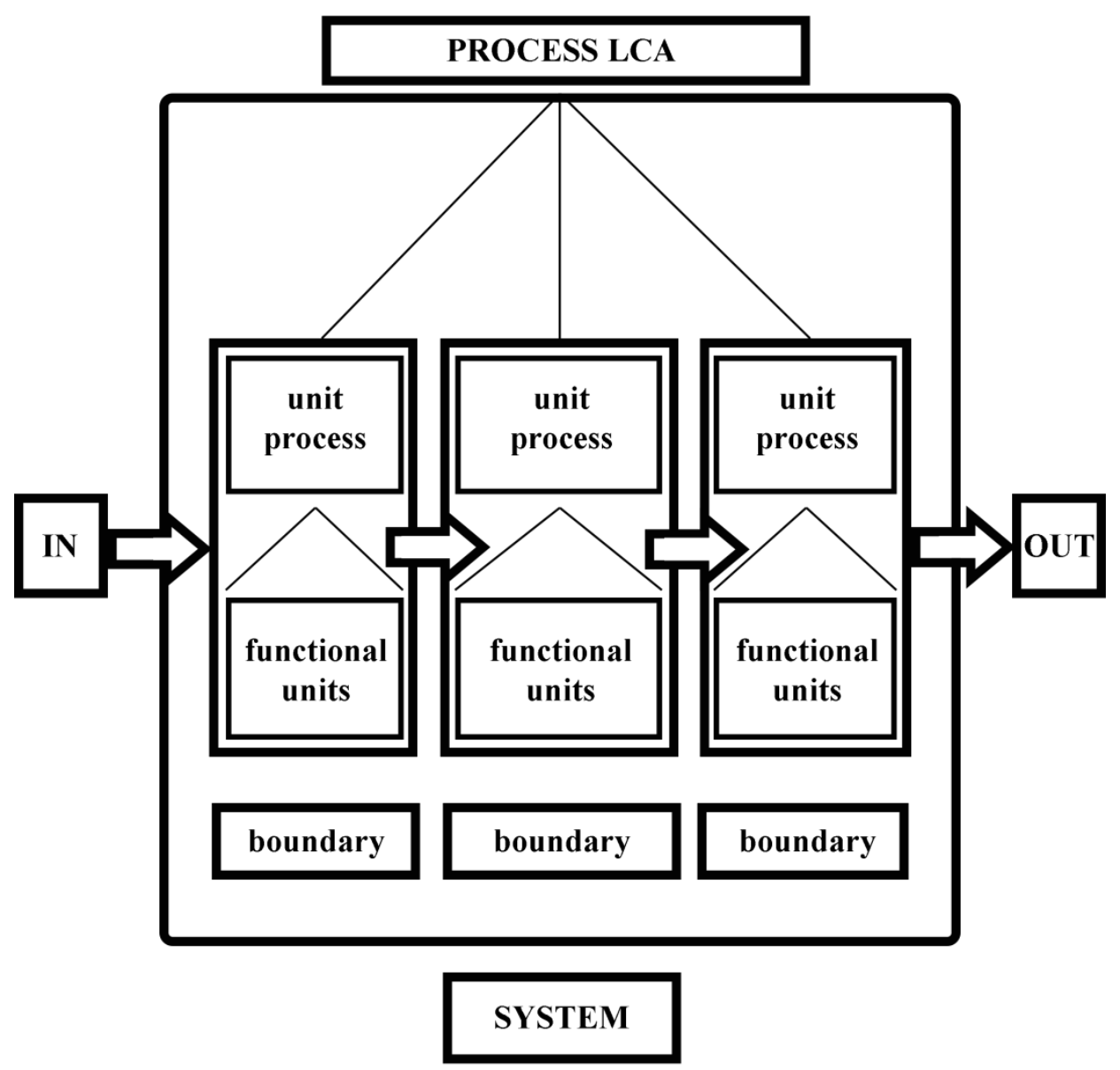

Figure 2. Schematic structure of LCA (Kulczycka, 2001) 
The manufacturing of a product is a set of material and energy unit processes combined. This collection meets one or more of the specific features of the process. Determination of the boundaries depends on the access to data. They should be specified at the beginning of the analysis and they should be identical for the compared products. The first step in determination of the scope of LCA will describe the system and its boundaries. This will allow for the analysis of the production process phases and determination of the required energy consumption in the process.

Functional units are the smallest units of the accepted term for studies that define the quantitative effect of the product system used as a reference unit in the research life cycle analysis (Sitnik, 2004). Functional units describe the reference plan for the normalization of input and output, which should be measurable. The determination of these units should be very precise during comparison of the two products for LCA. This analysis will allow for a real and meaningful comparison of the two products. Verification will enable exclusion of the initial stages of the life cycle or process unit, because the sensitivity analysis shows their lack of importance.

LCA is also used for the production of transportation fuels. The analysis is often divided into stages involving the production, processing and delivery of the product to a recipient. It is commonly used to evaluate the total energy consumption or efficiency of energy conversion and emission of toxic gases produced by motor vehicles (ISO 14044:2009).

This article shows a comparative analysis of the production process of two motor fuel types. The focus is on how much energy is needed for the production and distribution of 10,000 liters of diesel fuel and to produce the same amount of rapeseed oil and butanol (in the ratio of 2:3), and the assessment of the impact of the production of 10,000 liters of said fuels has on the environment.

\section{Production of motor fuels with using the LCA method}

Required steps in production of diesel oil are as follows:

- production of crude oil;

- transportation of crude oil to refineries;

- refining of crude oil into diesel fuel;

- transportation of diesel fuel to a petrol station.

Required steps in production of colza oil are as follows:

- cultivation of rape;

- transportation to a mill;

- extrusion of rape oil;

- production of butyl alcohol;

- transportation of fuel mixture to a recipient.

The total energy needed to produce 10,000 liters of diesel oil and colza oil with a mixture of butyl alcohol is shown in table 1 and table 2 and fig. 3 to fig. 6 . 
Assessment of the logistic system...

Table 1.

Energy required to produce 10,000 liters of diesel fuel (own study)

\begin{tabular}{lc}
\hline Process & $\begin{array}{c}\text { Energy consumption } \\
\text { (MJ) }\end{array}$ \\
\hline Extraction of crude oil & 1,113 \\
Transportation of crude oil to refineries & 201 \\
Refining of crude oil to diesel oil & 41,400 \\
Transportation of diesel fuel to a recipient & 2,954 \\
\hline Sum & 45,668 \\
\hline
\end{tabular}

Table 2.

Energy consumption during production and transportation of the mixture of rape oil and butyl alcohol (2:3 ratio) (own study)

\begin{tabular}{lc}
\hline Process & Energy consumption (MJ) \\
\hline Production of rape & $53,856.1$ \\
Transportation of rape to a company which presses them & $2,713.2$ \\
Extrusion of rapeseed oil & $1,684.8$ \\
Transportation of the rape oil and butyl alcohol mixture to a fuel & 114.43 \\
recipient & $58,368.53$ \\
\hline Sum &
\end{tabular}

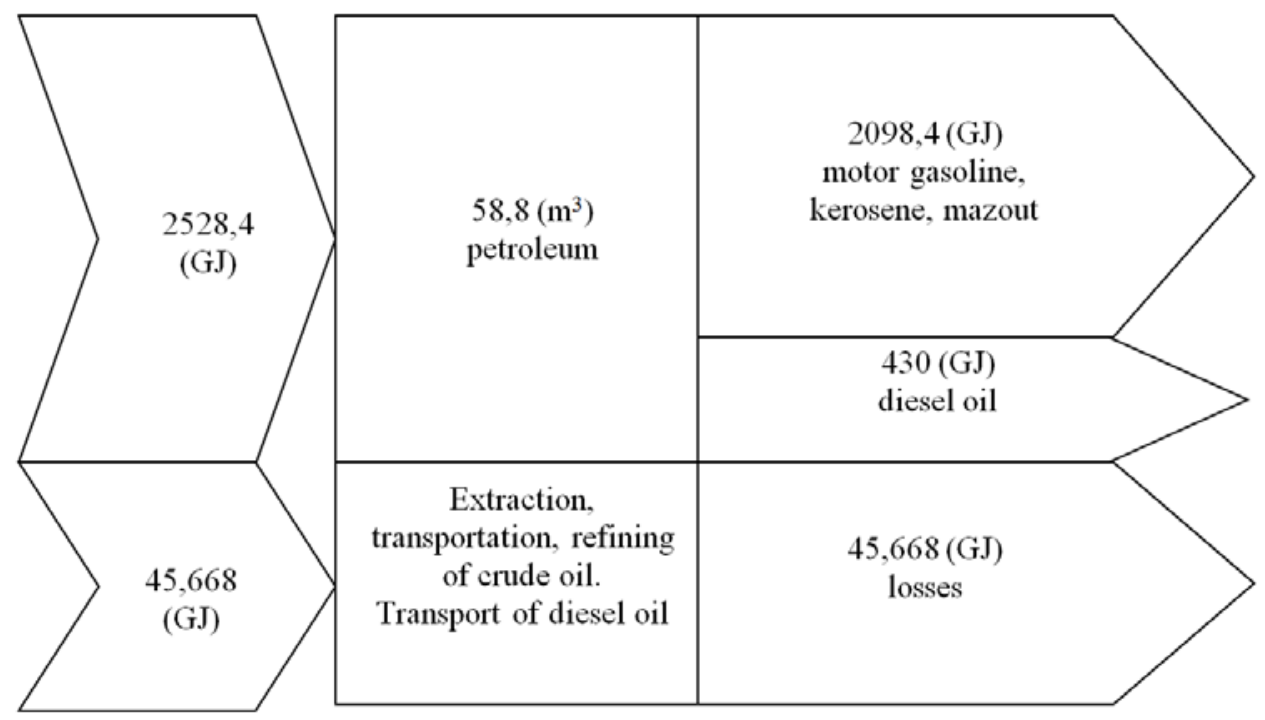

Figure 3. Energy balance of diesel oil life-cycle(own study) 
A. Marek, P. Kardasz, M. Karpinski, V. Pohrebennyk

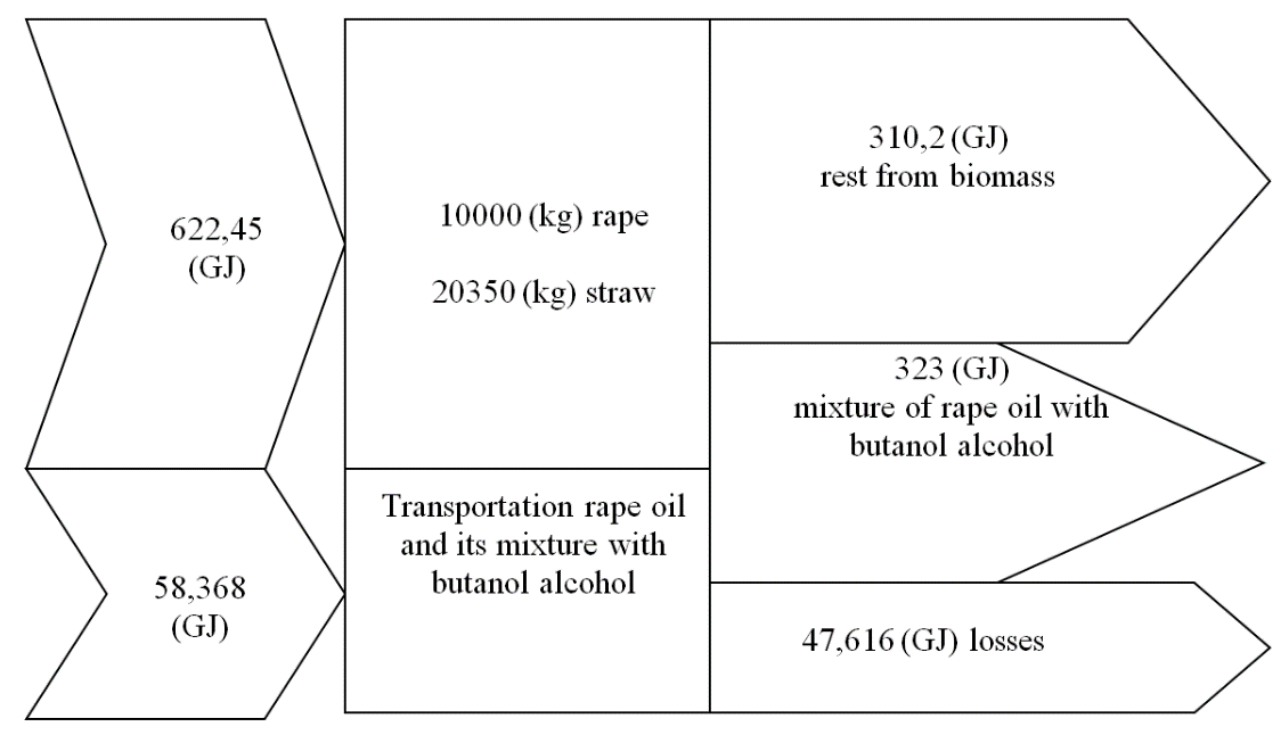

Figure 4. Energy balance of life cycle of rape oil mixed with butyl alcohol (ratio 2:3) (own study)

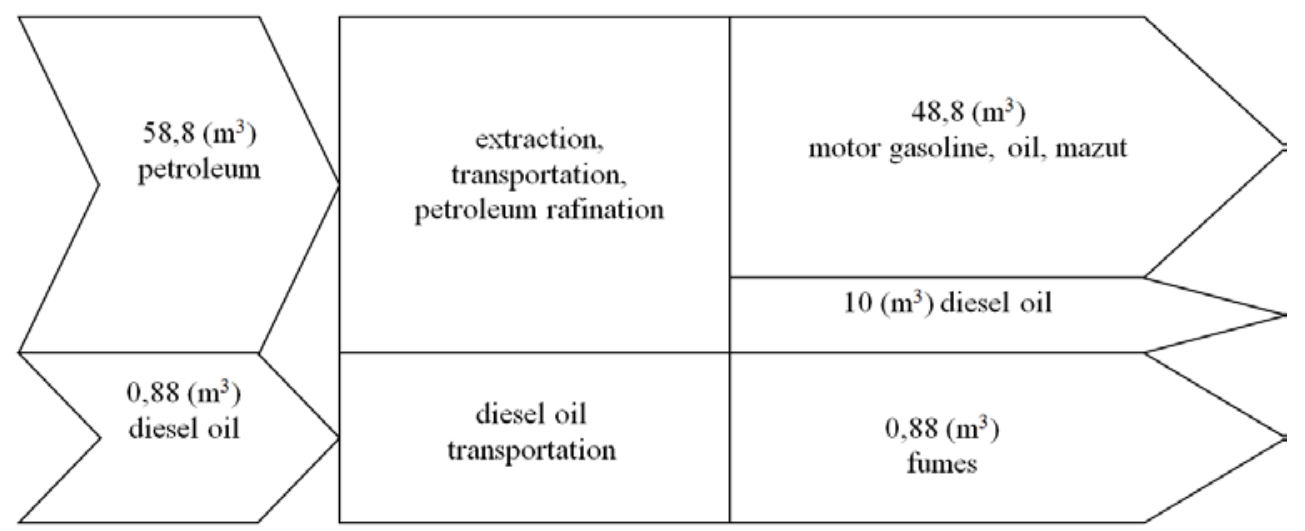

Figure 5. Balance of raw material sourcing 10,000 liters of diesel oil (own study) 
Assessment of the logistic system...

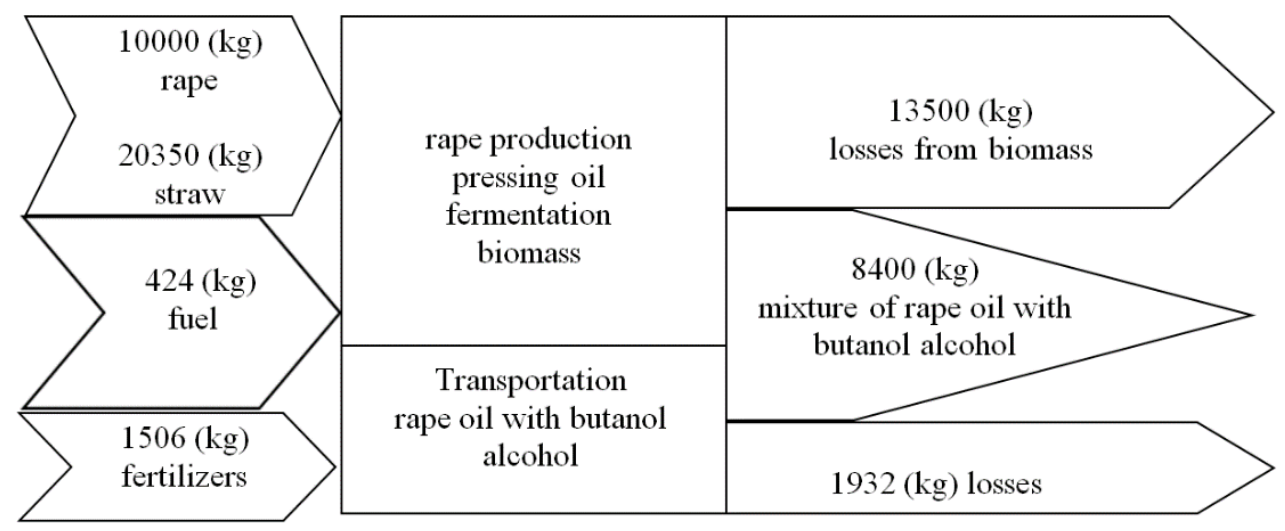

Figure 6. Balance of materials necessary to produce 10,000 liters of rape oil and butyl alcohol mixture (2:3 ratio) (own study)

Air emissions during the life cycle of diesel oil and air emissions during the life cycle of 10,000 liters of the rape oil and butyl alcohol mixture (2:3 ratio) are presented in tables 3 and 4.

Table 3 .

Air emissions during life cycle of diesel oil (own study)

\begin{tabular}{lccc}
\hline \multirow{2}{*}{ Process } & \multicolumn{2}{c}{ Emission (g/10,000 liters diesel oil) } \\
\cline { 2 - 4 } & $\mathrm{CO}_{\mathrm{x}}$ & $\mathrm{NO}_{\mathrm{x}}$ & $\mathrm{SO}_{\mathrm{x}}$ \\
\hline Production of crude oil & 6.8 & 16.4 & 89 \\
Transportation of crude oil to refineries & 0.2 & 1.3 & 7 \\
Refining a crude oil into diesel oil & 5,150 & 20,600 & 50,000 \\
Transportation of diesel fuel to a recipient & 2,516 & 10,698 & 363 \\
Using diesel oil in transportation company & 227,703 & 913,605 & 32,828 \\
\hline Sum & 235,376 & 944,921 & 83,287 \\
\hline
\end{tabular}


A. Marek, P. Kardasz, M. Karpinski, V. Pohrebennyk

Table 4.

Air emissions during life cycle of 10,000 liters of rape oil and butyl alcohol mixture (2:3 ratio) (own study)

\begin{tabular}{|c|c|c|c|}
\hline \multirow{2}{*}{ Process } & \multicolumn{3}{|c|}{ Emission (g/10,000 liters mixture) } \\
\hline & $\mathrm{CO}_{\mathrm{x}}$ & $\mathrm{NO}_{\mathrm{x}}$ & $\mathrm{SO}_{\mathrm{x}}$ \\
\hline Production of rape & 2,664 & 23,310 & 0 \\
\hline $\begin{array}{l}\text { Transportation of rape to a company which presses } \\
\text { them }\end{array}$ & 336 & 2,940 & 0 \\
\hline Extrusion of rapeseed oil & 6.72 & 42.24 & 162.24 \\
\hline $\begin{array}{l}\text { Fermentation of biomass and obtaining } \\
\text { butyl alcohol }\end{array}$ & 0 & 0 & 0 \\
\hline $\begin{array}{l}\text { Transportation of rapeseed oil and butanol mixture ( } 2: 3 \\
\text { ratio) to a fuel recipient }\end{array}$ & 33.6 & 294 & 0 \\
\hline $\begin{array}{l}\text { Use of rapeseed oil and butanol mixtures } \\
\text { ( } 2: 3 \text { ratio) as a fuel in a transportation company }\end{array}$ & 102,108 & 893,445 & 0 \\
\hline Sum & $105,148.32$ & $920,031.24$ & 162.24 \\
\hline
\end{tabular}

\section{Discussion}

To produce a functional unit of diesel fuel (i.e. 10,000 liters), $58.8 \mathrm{~m}^{3}$ of crude oil were extracted. The entire life cycle of 10,000 liters of diesel oil consumes 475.668 GJ of energy and causes emission to the atmosphere of the following selected substances: $235.376 \mathrm{~kg}$ of $\mathrm{CO}_{\mathrm{x}}, 944.921 \mathrm{~kg}$ of $\mathrm{NO}_{\mathrm{x}}, 83.287 \mathrm{~kg}$ of $\mathrm{SO}_{\mathrm{x}}$. Analyzing the production process of diesel oil, the most energy consuming and environment polluting is the process of refining the crude oil into diesel.

To produce a functional unit of the rape oil and butyl alcohol mixture (2:3 ratio) 10,000 $\mathrm{kg}$ of rape and $20,350 \mathrm{~kg}$ of rape straw should be used. The entire cycle of 10,000 liters of rape oil and a mixture of butyl alcohol (2:3 ratio) consumes 370.616 GJ of energy and causes the emission of the following substances into the atmosphere: $105.14832 \mathrm{~kg}$ of $\mathrm{CO}_{\mathrm{x}}$, $920.03124 \mathrm{~kg}$ of $\mathrm{NO}_{\mathrm{x}}, 0.162 \mathrm{~kg}$ of $\mathrm{SO}_{\mathrm{x}}$.

In the production of the rape oil and butyl alcohol mixture (2:3 ratio) the most energy consuming process is the cultivation of rape. Aside from that, a large amount of $\mathrm{CO}_{\mathrm{x}}$ and $\mathrm{NO}_{\mathrm{x}}$ is being emitted in the process due to the relatively long operation time of the agricultural machinery.

\section{Conclusion}

Production of diesel fuel requires more energy and causes a greater emission of pollutants. Thus, the use of rapeseed oil in a blend with butanol is more favorable. Striving to decreases energy consumption in the production of diesel oil should focus on refining crude oil. By changing of the oil production technology at this stage, the energy consumption and emission of sulfur oxides could be reduced. 
Assessment of the logistic system...

Using LCA in companies that decide to carry it out is beneficial to both the population and the environment at large. It indicates the possibility of realizing the interdependence between human activities and environmental consequences.

\section{References}

Gilecki, R. (2003). Zagadnienia importu paliw u progu XXI stulecia. Gospodarka paliwami. ISSN 0017-2413.

Gutkowski, J. (2002). Energia odnawialna - stan obecny w Polsce. Gospodarka Paliwami i Energią ISSN 0017-2413.

Góralczyk, M., Kulczycka, J. (2001). Ekologiczna Ocena Cyklu Życia (LCA) - nową normą z rodziny ISO 14000. Problemy Ekologii, 4, 151-155.

Kulczycka, J., Góralczyk, M., Koneczny, K., Przewrocki, P., Wąsik, A. (2001). Ekologiczna ocena cyklu życia (LCA) nowa technika zarządzania środowiskowego. IGSMiE PAN, Kraków. ISBN 83-87854-29-8.

Lagerstedt, J., Luttropp, C., Lindfors, L. G., Functional Priorities in LCA and Design for Environment, The International. Journal of Life Cycle Assessment, 8(3) 2003, 160-166.

Sitnik, L.(2004). Ekopaliwa silnikowe. Oficyna Wydawnicza Politechniki Wrocławskiej.

Piekarski,W., Szyszlak, J., Zając, G. (2006). Odnawialne źródła energii jako alternatywa paliw konwencjonalnych w pojazdach samochodowych. Agricultural Engineering, 4, 245-252.

Roszkowski, A. (2012). Biomasa i bioenergia - bariery technologiczne i energetyczne. Problemy Inżynierii Rolniczej 3(77), 79-100.

Stankiewicz, D. (2010). Możliwości wykorzystania surowców rolniczych do produkcji energii w Polsce. Studia BAS, Nr 1(21), 237-266.

Szczypiński-Sala, W. (2012). Niektóre własności mieszanin olejów roślinnych i paliw do silników o zapłonie samoczynnym. Mechanika. Czasopismo Techniczne 3, Wydawnictwo Politechniki Krakowskiej.

Szlachta, Z. (2002). Zasilanie silników wysokoprężnych paliwami rzepakowymi. WKL Warszawa, 25-42.

An Overview of FAME and Petroleum Diesel Life Cycles, NREL/TP-580-24772.

Poradnik stosowania biopaliw. Przykłady najlepszych zastosowań i projekty pilotażowe. Bałtycka Agencja Poszanowania Energii S.A. Opracowane w ramach projektu Bio-NETT Bio-NETT EIE/05/190/S12.420028.

ISO 14001. Environmental management systems. Requirements with guidance for use.

ISO 14040:2006. Environmental management. Life cycle assessment. Principles and framework.

ISO 14041. Environmental management. Life cycle assessment. Goal and scope definition and inventory analysis.

ISO 14042. Environmental management. Life cycle assessment. Life cycle impact assessment.

ISO 14043. Environmental management. Life cycle assessment. Life cycle interpretation.

ISO 14044:2009. Environmental management. Life cycle assessment. Requirements and guidelines. 


\section{OCENA SYSTEMU LOGISTYCZNEGO CYKLU ZYCIA PALIW PRZY WYKORZYSTANIU METODY LCA}

Streszczenie. W artykule przedstawiono ocenę systemu logistycznego cyklu życia paliwa, dla mieszanki oleju napędowego i oleju rzepakowego z butanolem (w stosunku 2:3), wykorzystując metodę LCA. Metoda ta jest techniką w zakresie procesów zarządzania, wykorzystywaną do oceny potencjalnych zagrożeń dla środowiska. Celem artykułu było porównanie zużycia energii potrzebnej do wytworzenia każdego z badanych paliw i emisji wybranych substancji powstających podczas procesu produkcyjnego. Badania przeprowadzono dla 10.000 litrów oleju napędowego i takiej samej ilości mieszaniny oleju rzepakowego i butanolu (w stosunku 2:3). Na podstawie pomiarów uzyskano następujące wyniki. W celu wytworzenia założonej ilości oleju napędowego (10,000 litra), wymagane jest wydobycie 58,8 $\mathrm{m}^{3}$ ropy naftowej. Podczas całego cyklu życia paliwa zużywa się 10.000 litrów oleju napędowego, co wymaga nakładu 475,668 GJ energii. Następuje wtedy emisja następujących ilości szkodliwych substancji do atmosfery: $\mathrm{CO}=235,376 \mathrm{~kg}, \mathrm{NO}_{\mathrm{x}}=944,921 \mathrm{~kg}, \mathrm{SO}_{\mathrm{x}}=83,287 \mathrm{~kg}$. Aby zapewnić funkcjonalność urządzenia przeznaczonego do wytwarzania mieszaniny oleju rzepakowego i butanolu (2:3) należy wykorzystywać $10000 \mathrm{~kg}$ rzepaku i $20350 \mathrm{~kg}$ słomy. Podczas całego cyklu życia 10.000 litrów mieszaniny oleju rzepakowego i alkoholu butylowego (2:3) zużywa się 370,616 GJ energii. Emisje wybranych substancji do powietrza są następujące: $C O=105,14832 \mathrm{~kg}$, $\mathrm{NO}_{\mathrm{x}}=920,03124 \mathrm{~kg}, \mathrm{SO}_{\mathrm{x}}=0,162 \mathrm{~kg}$. Analiza wyników prowadzi do wniosku, że najbardziej energochłonnym i emitującym najwięcej zanieczyszczeń procesem w cyklu życia diesel'a jest rafinacja ropy naftowej. Proces ten zużywa 41,4 GJ energii i prowadzi do emisji znacznych ilości tlenków siarki (50 kg). Przy produkcji mieszanki oleju rzepakowego i alkoholu butylowego (stosunek 2:3) najbardziej energochłonny jest proces produkcji rzepaku (pochłania 53,856 GJ energii) ze względu na długie czasy pracy ciągnika rolniczego i kombajnu. Podczas pracy tych maszyn emitowane są do środowiska duże ilości CO $(2,664 \mathrm{~kg})$ i NO$_{\mathrm{x}}(23,31 \mathrm{~kg})$.

Słowa kluczowe: cykl życia, system logistyczny, metoda LCA, zagrożenia dla środowiska 